\title{
Prevalence and Associated Risk Factors of Bee Lice in Holeta and its Suroundings, Ethiopia
}

\author{
Gizachew Gemechu ${ }^{1}$ \\ Alemu $^{2 *}$, Amssalu Bezabeh ${ }^{3}$ and Malede Berhan ${ }^{4}$ \\ ${ }^{1}$ Oromiya National Regional State Livestock agency, Ethiopia \\ ${ }^{2}$ Department of Veterinary Clinical Medicine, Faculty of Veterinary Medicine, University of Gondar, P.O. Box 196, Gondar, Ethiopia \\ ${ }^{3}$ Holeta Bee Research Center, Ethiopia \\ ${ }^{4}$ Department of Animal Production and Extension, Faculty of Veterinary Medicine, P.O. Box 196, University of Gondar, Gondar, Ethiopia
}

\begin{abstract}
A cross sectional study was carried out to determine prevalence of bee lice, and to find out associated risk factors in Holeta and its surroundings, West-Shoa zone of Oromia region. Of 385 bee colonies examined, overall prevalence of $42 \%$ lice infestation was observed. The highest prevalence $(70.8 \%)$ of bee lice was observed in Gemechis, followed by Holeta (50\%), while the lowest prevalence $(17.1 \%)$ was observed in Jaldu. Prevalence of lice observed in bees kept in apiary management system $(50.4 \%)$ had statistically significant difference $(P<0.05)$ to those bees kept in backyard (37.9\%). Higher prevalence of bee lice observed in medium altitude areas (50.4\%), was not statistically significant $(P>0.05)$ to that of highland areas $(40.4 \%)$. In conclusion, different level of prevalence of bee lice was observed among the different study sites, between medium land and high altitude areas, between apiary and backyard management system, and between types of hives. Therefore, bee keepers should be informed regarding factors affecting occurrence of bee lice, including altitude, management system, and type of hives to control bee lice in their hives. Further study on the distribution and magnitude, and financial impact of bee lice was suggested
\end{abstract}

Keywords: Bee lice; Colony; Holeta; Oromia; Prevalence

\section{Introduction}

Beekeeping is an important component of agriculture and rural development program in many countries [1], and useful smallscale efforts have been made to encourage beekeeping interventions throughout the world [2]. It plays a role in providing nutritional, economic, and ecological security. The business almost requires no land, capital, and does not take much part of the farmers' time, and does not compete with other components of farming systems for resources. Young and old people can be involved without gender restriction [1]. Directly, it contributes in the values of the outputs produced, including honey, bee wax, queen and bee colonies, and other products such as pollen, royal jelly, bee venom, and propolis in cosmetics and medicine $[3,4]$. Another very important contribution of beekeeping is through plant reproduction and conservation of the natural environment, and can be integrated with agricultural practices like crop production, animal husbandry, horticultural crops, and conservation of natural resources [5].

Large and diverse botanical resources combined with suitable climatic conditions make Ethiopia conducive for beekeeping business $[6,7]$, and the country is the leading honey producer in Africa, and is one of the ten largest honey producing countries in the world $[8,9]$. However, Ethiopian environment is not only favorable to bees, but also for different kinds of honeybee pest, including bee lice (Braula coeca), and predators that are interacting with the life of honeybees [10]. The bee lice are a wingless, ectoparasitic fly [11], which lives in honey bee colonies [12]. Female bee lice lay their eggs on honeycomb capping; upon emergence from their eggs, bee lice larvae construct a tunnel under the cell capping. It is also believed that bee lice larvae feed on honey and pollen residues encountered while tunneling under the cell capping [13]. Even though the main economic impact of braula fly occurs as a result of the larval stage burrowing under the cappings of honey combs, adult bee lice feed by stealing nectar directly from the mouths of honey bees [11]. A number of braula flies on a single queen can reduce the food available to the queen and impair her egg-laying ability, and also suggested as cause of supersedure [12].

The bee lice have an extensive global distribution, being documented in Africa, Asia, Europe, Australia (Tasmania), North America, and South America [13]. In Ethiopia, bee lice have been reported by different workers [10,14-16]. However, current prevalence and risk factors of bee lice is not well known in most parts of the country. Therefore, this study was carried out aiming to study prevalence, and to find out associated risk factors of bee lice in and around Holeta, Oromiya National Regional State, Ethiopia.

\section{Materials and Methods}

\section{Study area description}

The study was conducted in Holeta bee research center and its surrounding. The study area is situated at latitude of $9^{\circ} 3^{\prime} \mathrm{N}$ and longitude of $38^{\circ} 30^{\prime} \mathrm{E}$. The area has annual rain fall and daily temperature, which ranges from $834 \mathrm{~mm}$ to $1300 \mathrm{~mm}$ and $5^{\circ} \mathrm{C}$ to $28^{\circ} \mathrm{C}$, respectively. There were 2,973 bee hives in the study area [9].

\section{Study population}

The study population was bee colonies which were owned by Holeta bee research center apiary and bee colonies owned by farmers in

*Corresponding author: Sefinew Alemu, Department of Veterinary Clinical Medicine, Faculty of Veterinary Medicine, University of Gondar, P.O. Box 196, Gondar, Ethiopia, E-mail: sefiale@yahoo.com

Received December 14, 2012; Accepted January 17, 2013; Published January 19,2013

Citation: Gemechu G, Alemu S, Bezabeh A, Berhan M (2013) Prevalence and Associated Risk Factors of Bee Lice in Holeta and its Suroundings, Ethiopia. J Veterinar Sci Technol 4: 130. doi:10.4172/2157-7579.1000130

Copyright: (c) 2013 Gemechu G, et al. This is an open-access article distributed under the terms of the Creative Commons Attribution License, which permits unrestricted use, distribution, and reproduction in any medium, provided the original author and source are credited. 
Holeta and its surroundings. In the study area, bee colonies were kept in three categories of bee hives: traditional (1601colonies), transitional (648 colonies), and modern (674 colonies) bee hives. Traditional bee hives are kept under traditional management system, without any supplementary feeding and watering; bees forage by themselves. In most cases, bee hives are visited by owners only during honey cropping seasons. Transitional bee hives are managed better than the traditional one; hives are kept by farmers with technical assistance by extension workers. There is supplementary feeding like sugar syrup during forage scarcity in draught seasons. In the modern hives, Holeta bee research center, and in case of model hives, there is strengthening of weak colonies by uniting two or more weak colonies together. Plants flowering in different seasons were planted around, and there is supplementary feeding and watering to over winter bee colonies.

\section{Study design}

A cross-sectional study was employed from November, 2011 to March, 2012, in and around Holeta bee research center of Oromiya national regional state to determine prevalence of bee lice, and to find out associated risk factors. During sampling, one bee hive was considered as one colony. As there was no any significant difference in the management between traditional and transitional hives, the two bee keeping systems were grouped in to one category as backyard, while the modern bee farming system was taken as separate category. Types of hive, colony status, agro-ecology, and type of management were considered as explanatory variables (risk factors), and tested whether they have an impact on occurrence of bee lice or not. Based on colony status, hives were categorized into weak, medium and strong colonies. Colonies were grouped into weak when a colony had small number of worker bees, less defend enemies, and had little brood on comb; medium when it had moderate number of worker bees, defend enemies and had half full brood on comb; strong colony when it had high numbers of worker bees, defend enemies highly, and had comb filled with brood. Based on altitude, they were categorized as medium altitude (2500-3000 meters) and highland (1500 to 2500 meters), above sea level. Based on management, hives were categorized as backyard and apiary. Bee colonies were randomly selected and examined for the presence of bee lice.

\section{Sample size determination and sampling procedure}

The sample size required for the study was determined based on sample size determination in random sampling methods for infinite population, using expected prevalence of bee lice and 5\% desired absolute precision, according to Thrusfield [17] as follows:

$$
\mathrm{n}=\frac{1.96^{2} \mathrm{P}_{\exp }\left(1-\mathrm{P}_{\exp }\right)}{\mathrm{d}^{2}}
$$

Where: $\mathrm{n}=$ Required sample size

$$
\mathrm{P}_{\exp }=\text { Expected prevalence }
$$

\section{$\mathrm{d}=$ Desired absolute precision}

By using 50\% expected prevalence with $95 \%$ confidence interval at $5 \%$ absolute precision, the number of hives required to estimate prevalence of bee lice was calculated to be 384 .

A total of 385 bee colonies were collected from eight sampling sites, including Addisalem, Gemechis, Goleliben, Holeta, Jaldu, Muger, Sebeta, and Suba. Data was collected during night to reduce disturbance to bees and bee sting by wearing protective cloth and beekeepers' glove. About 50 bees were collected from each selected hive in a jar, using bee brush from hive entrance (externally), or from comb (internally), killed and preserved in 70\% methyl alcohol and labeled accordingly. Type of hive, colony status, agro-ecology and type of management were recorded corresponding to the label, and then transported to Holeta bee research center laboratory for bee lice examination.

\section{Examination procedure}

In the laboratory, preserved bee samples were taken and a detergent solution was poured into each of the jar containing bees up to half of the jar. Then the jar was shaken for 1 minute, until the lice separated from honey bees. The solution strained through a ladle (8-12 mesh) to remove the bees, and then sieving the solution through tea strainer. Finally, the tea strainer was examined for presence of bee lice by necked eye, and using hand lens [18].

\section{Data management and analysis}

Data analysis was conducted using SPSS version 20. Prevalence of bee lice was expressed as percentage by dividing total number of colonies positive for bee lice to the total number of samples or total number of colonies examined. Presence of association between risk factors and presence of bee lice was tested by using chi-square test.

\section{Results}

From the total of 385 bee colonies examined for presence of bee lice, $162(42 \%)$ were found infested with lice. The highest prevalence (70.8\%), while the lowest (17.1\%) was found in Jaldu (Figure 1), and the difference in prevalence of lice was statistically significant $(\mathrm{P}<0.05)$, among the sampling sites.

The highest prevalence of bee lice (48.5\%) was observed in traditional hives (Table 1), and there was statistically significant difference in prevalence of lice in bees kept in the different hive types $(\mathrm{P}<0.05)$.

When prevalence of bee lice was calculated in bees originated from high land and medium altitude areas, higher prevalence (50.4\%) was observed in bees originated from medium altitude areas (Table1). However, there was no statistically significant difference in prevalence of bee lice between the two study areas $(\mathrm{P}>0.05)$

Prevalence of bee lice was higher in bees kept in apiary management system (50.4\%) (Table 1), and there was statistically significant difference in prevalence $(\mathrm{P}<0.05)$ of lice between bees kept in apiary and backyard management.

When prevalence of bee lice was calculated based on colony

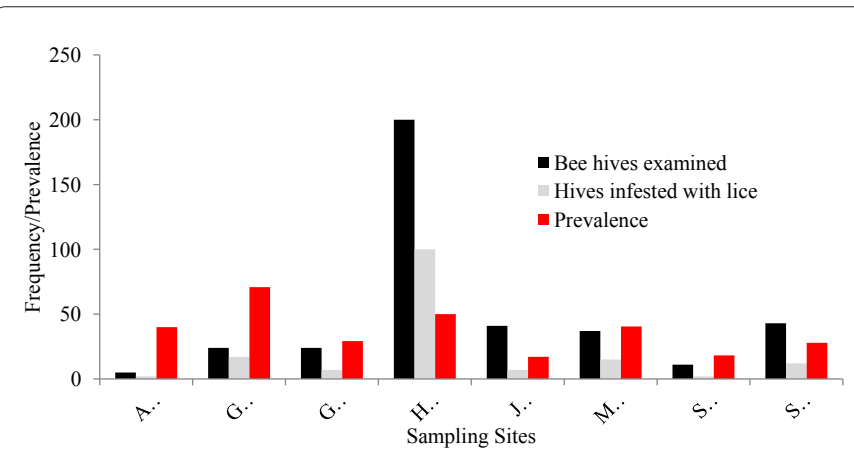

Figure 1: Prevalence of bee lice hives examined and infested with lice in the different sites. 
Citation: Gemechu G, Alemu S, Bezabeh A, Berhan M (2013) Prevalence and Associated Risk Factors of Bee Lice in Holeta and its Suroundings, Ethiopia. J Veterinar Sci Technol 4: 130. doi:10.4172/2157-7579.1000130

Page 3 of 4

\begin{tabular}{|l|c|c|c|}
\hline \multirow{2}{*}{ Risk factors } & Number of hives & Positive (Prevalence) & P-value \\
\hline Hive Type & Examined & & \\
\hline Modern & & & \\
\hline Transitional & 165 & $76(46.1)$ & 0.001 \\
\hline Traditional & 88 & $22(25)$ & \\
\hline Altitude & 132 & $64(48.5)$ & \\
\hline Highland & & & 0.125 \\
\hline Medium land & 322 & $130(40.4)$ & \\
\hline Type of Management & 63 & $32(50.4)$ & 0.019 \\
\hline Backyard & 256 & $97(37.9)$ & \\
\hline Apiary & 129 & $65(50.4)$ & \\
\hline Colony status & & & \\
\hline Weak & 163 & $67(40.9)$ & \\
\hline Medium & 142 & $61(43)$ & \\
\hline Strong & & & \\
\hline
\end{tabular}

Table 1: Prevalence of bee lice category and the different risk factors.

status, the highest prevalence of bee lice (43\%) was observed in strong colonies, while the lowest (40.9\%) was observed in weak colonies (Table 1). However, the difference in prevalence of bee lice was not statistically significant among bees of different colony status $(\mathrm{P}>0.05)$.

\section{Discussion}

The overall prevalence of bee lice (42\%) observed in the current study was much greater than other previous reports in Ethiopia. Gidey et al. [16] reported bee lice with prevalence of $4 \%$ and $5.5 \%$ in brood and adult honey bees, respectively; it was also higher than the work of Kinati et al. [15], Belie [19], who reported bee lice with prevalence of $11.2 \%$ and $12 \%$, respectively. However, Donson [20] reported bee lice with prevalence of $73 \%, 34 \%$ and $50 \%$ in the south-west region of England, west region of Wales, and central England, respectively. In a study done in Jordan, bee lice, Braula orientalis was detected from $64.3 \%$ of inspected apiaries and diagnosed in $45.4 \%$ of bee hives. The difference in prevalence of bee lice in the current and other previous studies might be associated with the difference in the method we followed in the examination of bee lice, and/or due to differences in the occurrence of bee lice in the different study areas associated with difference of environmental factors or management practices, or any other factor affecting occurrence of bee lice.

The highest prevalence of bee lice observed in traditional hive might be associated with the difference in the management practice; difference in hygienic condition might suit for multiplication and occurrence of bee lice. According to colony [21], maintaining high level of hygiene in all beekeeping practices and good husbandry contributes greatly to overall colony behavior and health, thereby avoiding conditions in which disease can flourish.

Higher prevalence of bee lice observed in medium altitude areas to that of highland might be associated with the difference in environmental factors like temperature, which might affect multiplication or survival of bee lice, or other concurrent infections or infestations. Temperature affects a colony, Coffey [22], described that development from egg to adult can be as little as 10 days, and as much as 23 days, depending on the temperature and, presumably, availability of capped comb honey in the hive. Higher prevalence of bee lice observed in the apiary might be associated with contact among colonies. Colonies in the apiary found close to each other, hence, facilitate transmission of bee lice among the colonies through swarming and drifting [12]. Chance of bees in apiary to visit same flower is higher than bees in backyard. Use of bee

keeping equipments for more than one colony, without proper hygienic condition can also facilitate transmission of bee lice among bee colonies $[21,22]$.

Highest prevalence of bee lice observed in the strong colony than of weak colony is not in agreement with other previous studies, and might be different method of categorizing the colony status. In conclusion, different level of prevalence of bee lice was observed among the different study sites, between medium land and high altitude areas, between apiary and backyard management system, and between types of hives. Even though impact of bee lice is considered less significant, it has its own contribution to affect hive production in the study area. Therefore, bee keepers should be informed regarding factors affecting occurrence of bee lice, including altitude, management system, and type of hives to control bee lice in their hives. Further study on the distribution and magnitude, and financial impact of bee lice was suggested.

\section{Acknowledgements}

Authors would like to thank Holeta Bee Research Center for allowing the laboratory and facilities. All the staff of Holeta Bee Research Center should be acknowledged for their cooperation; however, Bizunesh Danedena and Shewanesh Nagara desereve special appreciation.

\section{References}

1. http://www.apimo.dk/africa/afrika-1.htm

2. Bradbear N (2004) Beekeeping and sustainable livelihoods. Agricultural Support Systems Division, Food and Agriculture Organization of the United Nations, Italy.

3. ARSD (Apiculture Research Strategy Document) (2000) Apiculture research strategy document. EARO (Ethiopian Agricultural Research Organization) Addis Ababa, Ethiopia.

4. Gezahegn T (2001) Apiculture development strategies. Ministry of Agriculture and Rural Development, Addis Ababa, Ethiopia.

5. http://www.odi.org.uk/speeches/gibbon.pdf

6. Nuru Adgaba, Admasu Adi, Dereje Woltdje (2001) Pollen sectrum of honeys and honey bee floral calander of West Shoa. Third National Annual Conference of the Ethiopian Beekeepers Association, Addis Ababa, Ethiopia.

7. Desalegn B (2007) Assessment of the effect of ant on honey bee colony and their product in west and south-west Shewa zone. Ethiopian Journal of Animal Production 7: 12-26.

8. Ayalew K (1990) The honey bees (Apis Mellifera) of Ethiopia. A morphometric study. Agricultural University of Norway, Norway.

9. CSA (Central Statistical Agency) (2007) Agricultural sample survey of 2007 Volume II report on Livestock and Livestock Characteristics. Central Statistical Agency, Addis Ababa, Ethiopia.

10. Desalegn B (2003) Level terminal annual report. Holeta Bee Research center Holeta, Ethiopia.

11. Smith IB, Caron DM (1985) Distribution of the bee lice, Braula coeca, in Maryland and worldwide. American Bee Journal 125: 294-296.

12. Somerville D (2007) Braula fly. Primefact 649.

13. http://edis.ifas.ufl.edu/pdffiles/IN/IN84500.pdf

14. Alemayehu G (2010) Terminal report. Holeta Bee Research center, Holeta, Ethiopia.

15. Kinati C, Tolemariam T, Debele K, Tolasa T (2012) Opportunities and challenges of honey production in Gomma district of Jimma zone, South-west Ethiopia Journal of Agricultural Extension and Rural Development 4: 85-91.

16. Gidey A, Mulugeta S, Fromsa A (2012) Prevalence of bee lice Braula coeca (Diptera: Braulidae) and other perceived constraints to honey bee production in Wukro Woreda, Tigray region, Ethiopia. Global Veterinaria 8: 631-635.

17. Thrusfield M (2005) Veterinary epidemiology. ( $3^{\text {rd }}$ edn), Blackwell publishers, London. 
Citation: Gemechu G, Alemu S, Bezabeh A, Berhan M (2013) Prevalence and Associated Risk Factors of Bee Lice in Holeta and its Suroundings, Ethiopia. J Veterinar Sci Technol 4: 130. doi:10.4172/2157-7579.1000130

Page 4 of 4

18. http://files.uniteddiversity.com/Beekeeping/A_Practical_Manual_of_ Beekeeping.pdf

19. Belie T (2009) Honey bee production and marketing systems, constraints and opportunities in Burie district of Amhara region, Ethiopia. MSc thesis (Animal Production), Bahir Dar University, Ethiopia.

20. Donson JR (1999) Bee lice' Braula Schmitz Orosi-PAL (Dipteria Braulidae) new to the British Isles, and the status of Braula species in England and Wales. British Journal of Entomology and Natural History 11: 139-148.

21. http://www.edinburghbeekeepers.org.uk/diseases/Braula1.pdf

22. Coffey FM (2007) Parasites of the honeybee. The Department of Agriculture, Fisheries and Food, Crops Research Centre, Oak Park, Carlow, Ireland. 